\title{
Real-virtual monte carlo simulation on impulse-momentum and collisions
}

\author{
Wartono $^{1}$, Dwi Hartoyo ${ }^{2}$, Nilasari ${ }^{3}$, John Rafafy Batlolona ${ }^{4}$ \\ 1,2,3 Department of Physics, Faculty of Mathematics and Natural Sciences, State University of Malang, Indonesia \\ ${ }^{4}$ Primary School Teacher Education Study Program, Teaching and Education Faculty, Pattimura University, Indonesia
}

\begin{tabular}{|c|c|}
\hline Article Info & ABSTRACT \\
\hline Article history: & \multirow{9}{*}{$\begin{array}{l}\text { This study aims to determine the differences in scientific literacy of students } \\
\text { who were given inquiry learning through a real-virtual Monte Carlo } \\
\text { experiment with students who were given conventional learning. This study } \\
\text { used quasi experimental design with pretest-posttest control group. } \\
\text { The results showed that the ability of students who were taught by inquiry } \\
\text { learning models through real-virtual Monte Carlo experiments had higher } \\
\text { scientific literacy than those taught with conventional models, it also applied } \\
\text { well to students with high and low initial abilities. The results of the average } \\
\text { gain in scientific literacy scores also showed a higher value between students } \\
\text { who studied with the inquiry model through a real-virtual Monte Carlo } \\
\text { experiment with students who studied with conventional models. The novelty } \\
\text { of this research is combining real and virtual activities become real-virtual } \\
\text { Monte Carlo by using the inquiry learning model to improve students' } \\
\text { scientific literacy. }\end{array}$} \\
\hline Received Jul 17, 2018 & \\
\hline Revised Sep 18, 2018 & \\
\hline Accepted Oct 2, 2018 & \\
\hline Keywords: & \\
\hline Inquiry & \\
\hline Real-virtual & \\
\hline Scientific literacy skills & \\
\hline & \\
\hline
\end{tabular}

Copyright $(0) 2019$ Institute of Advanced Engineering and Science. All rights reserved.

\section{Corresponding Author:}

John Rafafy Batlolona,

Primary School Teacher Education Study Program,

Teaching and Education Faculty,

Pattimura University, Indonesia.

Email: johanbatlolona@gmail.com

\section{INTRODUCTION}

Physics is one of the fields of science that has very complex characteristics compared to other sciences [1-2]. Learning physics requires a good concept [3], physical interpretation skills [4], transformations of quantities and units as strengths in increasing students' knowledge [5]. Therefore, physics is still considered as one of the difficult fields of science by students [6-7]. The real science of learning physics is not only to find a solution to the equation, but also to learn to describe a phenomenon, and to understand the physical system [8-10]. Other scientists argue that mathematics is very important for relating scientific concepts [11]. Mathematical and physical are also considered to be very close and interact with one another [12]. Therefore, teaching physics to students requires mathematical knowledge, concepts about what is known and unknown, how to solve problems, making problem solving planning, making stages of problem solving, giving reasons why solving problems in the way they go, monitoring the learning process and its progress towards the goal when implementing the plan, and evaluating what is done is one complete science for a teacher [13-15]. In addition to these abilities, one of the abilities that is considered important, especially in the world of science, is scientific literacy skills. Science literacy means being able to apply concepts or facts obtained in school with natural phenomena that occur in everyday life [16].

The scientific literacy is important to be owned by students in the 21 st century. The formation of scientific literacy skills in students especially in Indonesia is not an easy matter especially when viewed from the results of PISA international studies in 2015, students' scientific literacy abilities are not at level 5 and 6 at rank 62 of 70 countries [17]. This means that it can be said that Indonesian scientific literacy abilities are 
in a low level. Therefore students need to be well equipped with scientific knowledge and able to compete with developed countries such as Singapore, Australia, the United States, Russia and the United Kingdom.

One learning model that can facilitate students' scientific literacy skills is inquiry. Inquiry is one of the learning models offered in the 2013 curriculum. Inquiry learning is a learning model designed to conduct experiments [18-19]. Based on the media, there are two types of experiments, namely real experiments and virtual experiments. Combining both real experiments and virtual media will produce the ability of qualified students. Real experiments will provide meaningful new experiences to students in the process of finding concepts, and confirming errors during practicum [20] while virtual confirms students' knowledge through computer simulations [21]. Previous research used only one variable, namely a virtual simulation [22], but in this study combining real and virtual called real-virtual Monte Carlo. The inquiry learning model through real-virtual experiments is a learning model that is expected to influence students' scientific literacy. To find out whether there is influence in literacy, the purpose of this research was to find out the effect of inquiry learning models through real-virtual experiments on the ability of scientific literacy on the topic of ImpulseMomentum and Collision with different classes.

\section{RESEARCH METHOD}

\subsection{Research design}

This study used quasi experimental method with pretest-posttest control group design. The research design chosen was a two-factor factorial design [23]. This research was conducted on two different classes, namely experimental and control classes. The experimental class was treated by inquiry learning model through a real-virtual Monte Carlo experiment while the control class was treated by conventional learning, namely the learning model commonly applied by the physics teacher of senior high school 1 in Dampit city.

a) Population and Research Sample

The population in this study was all students of tenth grade of science class in of state senior high school 1 in Dampit city. The research sample consisted of two classes chosen by random sampling or random cluster namely tenth grade of science class 5 as experimental class and tenth grade of science class 6 as the control class. There are two variables in the study namely independent and dependent variables. The independent variables of the learning model are inquiry through real-virtual experiments in the experimental class and conventional learning models in the control class. Dependent variables are scientific literacy of students.

b) Research Instruments

In this study, the measurement instruments compiled are observation sheets to see the implementation of inquiry learning through real-virtual experiments in the experimental class and the scientific literacy instrument consisting of 7 questions related to scientific literacy material about impulsemomentum and collisions. A case or problem in daily life was given in every question to measure students' scientific literacy. The issue of scientific literacy can be shown in Table 1. Item of scientific literacy is used as a measuring tool for scientific literacy skills of students after being treated with the inquiry learning model through real-virtual experiments and conventional learning in the control group.

Table 1. Questions of Scientific Literacy

\begin{tabular}{|c|c|c|}
\hline No & Literatures & Questions \\
\hline 1. & $\begin{array}{l}\text { Softball is a team ball sport consisting of two teams. Softball } \\
\text { games born in the United States, created by George Hancock in } \\
\text { the Chicago city in } 1887 \text {. Softball is a development of a kind of } \\
\text { sport that is baseball (baseball) or hardball. Softball balls are } \\
\text { currently } 28-30.5 \mathrm{~cm} \text { in diameter; The ball is thrown by a pitcher } \\
\text { and becomes the target of the opponent who hits the batter using a } \\
\text { bat. There is a team on guard (defense) and teams that hit } \\
\text { (offense). Each team competes to collect runners by circling three } \\
\text { series of runners to touch the final markings, home plate. }\end{array}$ & $\begin{array}{l}\text { You're sitting watching a softball game when the ball } \\
\text { hit by the player is heading towards you. You will } \\
\text { catch the ball by hand. To catch the ball safely, what } \\
\text { will you do: First, you will move your hand towards } \\
\text { the ball or, Second, catch the ball while backwards } \\
\text { following the direction of the ball? Explain your } \\
\text { reason? }\end{array}$ \\
\hline 2. & $\begin{array}{l}\text { The overloaded container truck that carried log paper experienced } \\
\text { brake failure in the Pasuruan, East Java area that caused the } \\
\text { collision in a row. The truck drove from Malang direction, the } \\
\text { truck stopped after crashing into } 6 \text { vehicles in front of it. Where } 2 \\
\text { of the } 6 \text { vehicles were dragged along and joined together while } \\
\text { the other } 4 \text { vehicles bounced far ahead. } \\
\text { Source: liputan } 6 \text { (January } 29^{\text {th }} 2018 \text { at } 12.57 \text { Western Indonesian } \\
\text { Time) }\end{array}$ & $\begin{array}{l}\text { Based on the literature, identify the vehicle based on } \\
\text { the types of collisions and explain in detail. }\end{array}$ \\
\hline
\end{tabular}


c) Data collection technique

Data collection in the study was carried out in stages to be able to obtain the data needed in a study. There are three stages of data collection in this study. The stages of data collection include. 1) the research preparation phase, 2) the research implementation phase (Prestest, Learning Activities and Posttest). 3) the closing phase of the research includes the activity of collecting the results of the research implementation data and processing the data so that it becomes a research report.

d) Data analysis

Data analysis is a process of testing the research hypotheses that have been formulated previously. The data tested were gain data on students' scientific and metacognitive literacy scores. Data gain scores are obtained from the results of a reduction in the posttest scores of students with the results of the students' pretest for both scientific literacy and metacognitive data. Metacognitive questionnaire data and scientific literacy data were analyzed quantitatively with data analysis steps, namely. 1) Normality Test, 2) Homogeneity Test, 3) Similarity Test, 4) Hypothesis Test Research using Two-way ANOVA using SPSS Type 16.

\section{RESULTS AND ANALYSIS}

in Table 2.

The results of students' initial ability data both control and experimental classes can be seen

Table 2. Summary of Students' Initial Ability Results

\begin{tabular}{lcccc}
\hline Variable & $\begin{array}{c}\text { The number } \\
\text { of students }\end{array}$ & Average & $\begin{array}{c}\text { The Highest } \\
\text { Scores }\end{array}$ & $\begin{array}{c}\text { The Lowest } \\
\text { Scores }\end{array}$ \\
\hline Experiment Class & 34 & 74,6 & 83 & 68 \\
Control Class & 34 & 72,7 & 80 & 68 \\
\hline
\end{tabular}

Table 2 shows the average value of the initial ability of the experimental class was 74.6 and the control class was 72.7 with the number of students as much as 34 . Then the similarities were tested using the two-tailed T-test, with the results can be seen in the Table 3.

Table 3. Summary of T-Test of Students' Initial Capability Data

\begin{tabular}{cccccc}
\hline Classes & $\mathrm{N}$ & $\mathrm{X}$ & $\mathrm{Sd}$ & $\mathrm{T}_{\text {count }}$ & $\mathrm{t}_{\mathrm{tab}}$ \\
\hline Experiment & 34 & 74,6 & 4,40 & 1,95 & 2,03 \\
Control & 34 & 72,7 & 3,02 & & \\
\hline
\end{tabular}

Based on Table 3, it is obtained the results of the test $t$ count $=1.95$, this means that the Ho reception area is between -2.03 and +2.086 it can be concluded that the initial ability of students in the experimental class is the same as the control class.

Table 4. Summary of Results of Science Literacy Score Gain

\begin{tabular}{lcccc}
\hline Variable & The number of students & Average & The Highest Scores & The Lowest Scores \\
\hline Experiment Class & 34 & 42,8 & 61,9 & 14,2 \\
Control Class & 34 & 19,5 & 57,1 & 4,7 \\
\hline
\end{tabular}

Based on Table 4 in the control class, the average value of scientific literacy is 19.5 and in the experimental class 42.8. Research hypothesis testing used Two-Way ANOVA test both experimental and control classes and can be seen in Table 5.

Table 5. Summary of Results of Two-way ANOVA Science Literacy

\begin{tabular}{lccccrc}
\hline Source of Variation & SS & df & MS & Fcount & P-value & F table \\
\hline Initial Inter-Ability (B) & 1333.5 & 1 & 1333.5 & 13.62683 & 0.000826 & 4.149097 \\
Inter Learning (A) & 4038.6 & 1 & 4038.6 & 41.27088 & 3.2 E-07 & 4.149097 \\
Interaction & 90.567 & 1 & 90.567 & 0.925513 & 0.343245 & 4.149097 \\
Within & 3131.4 & 32 & 97.85597 & & & \\
Total & 8594 & 35 & & & & \\
\hline
\end{tabular}


Based on Table 5, the results of Fhit> Ftable are obtained with a value of 5.11>4.15 for interlearning variant data (A) so that the Ho hypothesis is rejected and $\mathrm{Ha}$ is accepted. It can be concluded that students' metacognitive learning with inquiry learning models through real-virtual experiments is higher than the class taught by conventional models.

Furthermore, for variance data between initial capabilities (B), the results of Fhit> F tab are obtained with a value of 9.40> 4.15 so that the Ho hypothesis is rejected and $\mathrm{Ha}$ is accepted. It can be concluded that the increase in metacognitive high-low initial ability students who learned the inquiry model through realvirtual experiments was higher than conventional classes.

The display of experimental virtual activities used Phet computer simulations to reconstruct student knowledge on topics of momentum, impulses and collisions as shown in Figure 1.
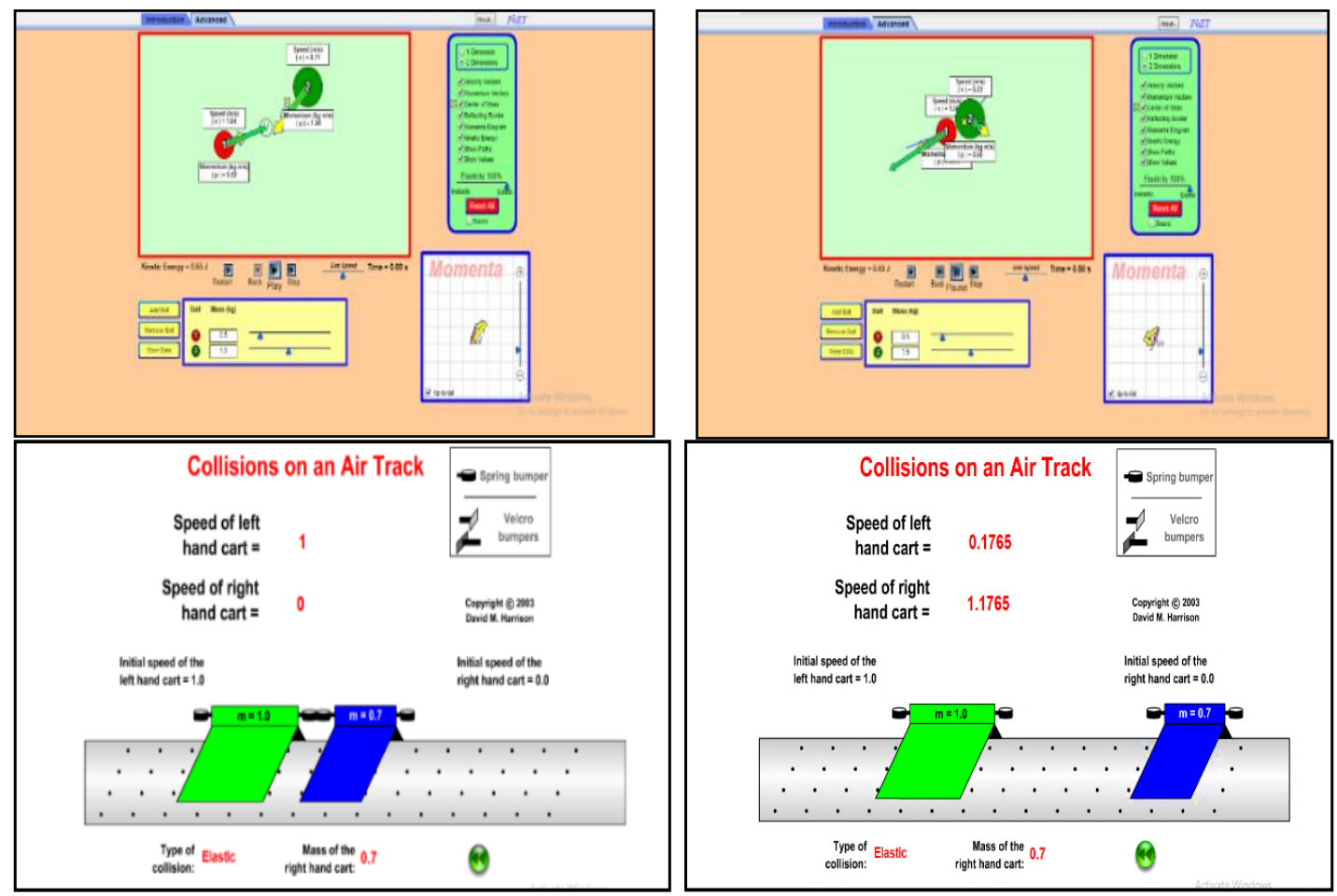

Figure 1. Virtual experiment activities (Phet Colorado, 2018) [24]

Based on the average value and hypothesis testing, it can be concluded that students who are taught by the inquiry model through real-virtual Monte Carlo experiment are able to improve scientific literacy higher than conventional, both in groups of students with high and low initial abilities. Those who study with the inquiry model through real-virtual Monte Carlo experiment do more practicum and during the learning activities the teacher provides many examples of application in everyday life. In the inquiry activity, students learn to explain phenomena and make conclusions based on experiments. During learning activities, students are divided into several heterogeneous groups, namely students who have different abilities. Activities that are carried out in groups will have a good impact on students' scientific literacy, especially if in one group they have different levels of ability because of the transfer of learning from students who have high ability to students who have low ability. This is in line with the understanding of scientific literacy put forward by the OECD 2012 that someone is said to have good scientific literacy if the individual is able to explain scientific phenomena, and draw conclusions based on concrete evidence of science related to problems. Through inqury students are given learning videos about topics of momentum, impulses and collisions for some cases in the real world. One example is in Figure 2, by the phenomenon of collisions on cars, students will reconstruct their knowledge well. 


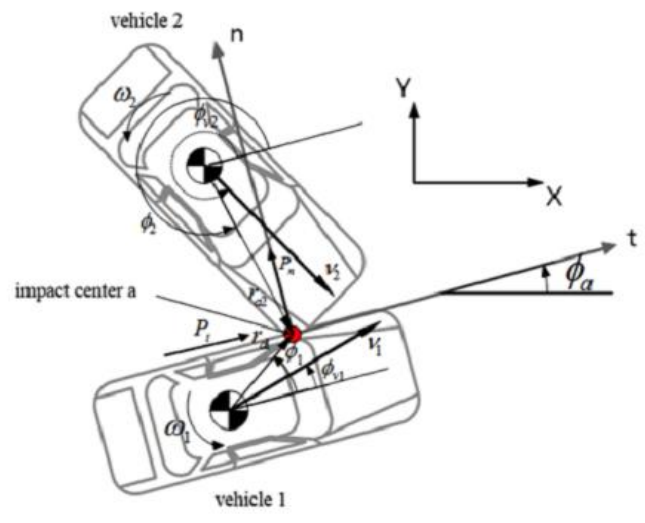

Figure 2. The phenomenon of collisions on cars (Han, 2015) [25]

The results of previous studies prove that students still have difficulties in learning the concepts of energy, momtentum and conservative style [26]. Many students are still not able to connect momentum and impulse [27-28] but with real-based virtual learning with inquiry learning models, students are so enthusiastic because students feel complete with learning. The learning activities are usually only conventional. Students feel modern learning both animation or computer simulation and real experimentation give them better understanding about the concept. It also generates enthusiasm for learning all the time. By the results of the research or the Two-way ANOVA statistical test, there is a significant difference between the incuriate class and the conventional class. Where the teacher is no longer a primary learning source, but students who are trying to learn, find and solve problems. Science is higher than students who study with conventional learning models.

a. Differences in improved science literacy for students who have high-low initial ability

The results of the two-way ANOVA test that has been described previously, it can be seen that the significant difference in students' scientific literacy between high initial ability and low initial ability. This is where the role of inquiry learning through real-virtual Monte Carlo experiments of initial ability is seen, when two classes are given different treatment from classes that use inquiry through real-virtual Monte Carlo experiments high initial ability groups and classes that do not use inquiry through real-virtual Monte Carlo experiments with low initial ability group.

The initial ability of students can be formed through various ways, one of them is by doing good apperception. Apperception carried out in the early stages of learning can generally be considered small, but the impact is large on the learning process. The unfamiliarity of students in solving a problem or in the process of finding a concept turned out to be strongly influenced by immaturity during apperception which resulted in the ultimate goal of learning not being achieved or not in line with expectations.

In inquiry learning, students are grouped into several groups through the real-virtual Monte Carlo. This is what can foster a sense of good cooperation in one group. The process of learning collaboratively in one group allows students to remember longer the lessons they receive, the problem-solving discussion together so that mutual interactions occur among members.

Students' scientific literacy skills between the experimental class and the control class at high-low initial ability have significant differences. If it is related to inquiry learning through real-virtual Monte Carlo experiment, students who have high initial ability are supported by learning that prioritizes the science process, it will produce good scientific literacy as well as the emergence of students' scientific literacy with science processes and conceptual understanding of science itself. Likewise, the group work activity makes the transfer of knowledge from smart students to students with low abilities in each group, so as to give a good impact on each group. The initial ability of physics possessed by students will contribute greatly in predicting the success of subsequent student learning [29]. Based on this description, it shows the influence of the initial ability in inquiry learning through real-virtual Monte Carlo experiments on students' scientific literacy.

b. Effect of inquiry learning models through virtual-rill experiments on science literacy

The results of the data analysis of the influence of the learning model on scientific literacy using ANOVA test concluded that there is an influence between the inquiry models through the real-virtual Monte Carlo experiment with scientific literacy. Previous findings suggest that the inquiry learning model resulted in an increase in students' scientific literacy [29]. 
The increase in the average value of students' scientific literacy is inseparable from the characteristics of the inquiry model syntax through the real-virtual Monte Carlo experiment. Inquiry through real-virtual Monte Carlo experiment is a learning model that emphasizes inquiry activities. The principle of implementing learning with the inquiry model through real-virtual Monte Carlo experiments is in the process of inquiry where students are required to investigate and test the hypotheses that have been made. Inquiry activities through a real-virtual Monte Carlo experiment emphasize the active role of students during learning. Students actively acquire the concept of their own knowledge so that knowledge can be remembered longer by students and learning will be meaningful. The results of interviews from several students, students feel happy and motivated in learning with the inquiry model through the real-virtual experiment of Monte Carlo. This is because students find it easier to understand material when it is done using the inquiry model through a real-virtual Monte Carlo experiment. This statement is supported by Howes et al., (2009) [30] which state that inquiry learning emphasizes the maximum student activity to look for and find, meaning that this learning places students as subjects of learning.

The inquiry model through the real-virtual Monte Carlo experiment is able to develop students' thinking skills as part of the mental process. Thus, students are not only required to master the subject matter in inquiry, but how students can relate material with the surrounding environment. This is what makes students literate or aware of the science of the environment, both those who interact and not. Developing students 'scientific literacy will increase along with the learning model used. Therefore learning must empower students' thinking skills [31]. Inquiry learning through the real-virtual Monte Carlo experiment trains students to discuss in formulating problems, making hypotheses, collecting data, testing hypotheses and making conclusions from what has been obtained. Work activities in peer groups will be a vehicle for students to improve students' scientific literacy.

Science literacy is individual scientific knowledge and the use of that knowledge to identify questions so that new knowledge is obtained to explain scientific phenomena, and to draw evidence-based conclusions about science related to problems, understanding the characteristics of science as a form of human knowledge and inquiry (OECD, 2015). All activities in inquiry through real-virtual Monte Carlo experiments lead to students' scientific literacy abilities.

It can be seen that the superiority of the inquiry learning model through real-virtual Monte Carlo experiments can develop students' thinking through the phenomena investigated. Inquiry learning models have advantages, including; 1) Emphasizing three aspects of skills, namely cognitive, affective, and psychomotor. 2) Students become active and productive in finding and processing information. 3) Students can better understand basic concepts and ideas. 4) Providing opportunities for students to learn according to their learning styles. 5) Students who have high abilities will not be hampered by students who have low ability in learning. 6) Helping students in using memory in transferring their concepts to new learning processes. 7) Encouraging students to think constructively and formulate their own hypotheses. 8) Forming and developing their own concepts in students so that psychologically students are more open to new experiences, willing to always take and exploit opportunities. 9) Allowing students to learn not only from the teacher but also by utilizing various types of sources [32].

After receiving inquiry learning through real-virtual Monte Carlo experiments, students have the ability to think high level [33], find concepts and associate concepts with the natural phenomena of the surrounding environment [34]. It can be seen from the students' answers before inquiry learning through realvirtual Monte Carlo experiments, students have not been able to express answers in detail and correspond to concepts. Students only guess and think using logic. In contrast to after having been given an inquiry learning model through, a real-virtual Monte Carlo experiment students are better able to express answers correctly and in accordance with the concepts they already have. The results of this study indicate that inquiry learning through real-virtual Monte Carlo experiment influences students' scientific literacy. The characteristics possessed through real-virtual experiments can create meaningful learning. In addition, the problems used are contextual and familiar to students, so students can explore their abilities with information related to the problem that comes from their own experience and can make good decisions because students experience it immediately.

\section{CONCLUSION}

Based on the results of the study and discussion it can be concluded that the ability of students who learn with the inquiry model through real-virtual Monte Carlo experiments in scientific literacy is higher than students who study with conventional learning models. These results are supported by the Two-way ANOVA hypothesis test which states that class science literacy skills with the inquiry model through a real-virtual Monte Carlo experiment are higher than conventional classes for both groups of students with high or low initial abilities. Thus the inquiry model through the real-virtual Monte Carlo experiment can be 
recommended in improving students' scientific literacy. The novelty of this research is combining real and virtual activities with the real-virtual Monte Carlo by using inquiry learning models to improve students' scientific literacy. The limitation of this research is only measuring inquiry model on scientific literacy. Therefore, the next studies are suggested to measure students' literacy activities at each meeting and scientific literacy misconceptions in each literature given by the teacher.

\section{REFERENCES}

[1] Rinia, E. J., van Leeuwen, T. N., Bruins, E. E. W., van Vuren, H. G., \& van Raan, A. F. J. "Measuring Knowledge Transfer Between Fields of Science”. Scientometrics. 2002. 54(3), 347-362.

[2] Irving, P. W.,\& Sayre, E. C. "Physics Identity Development: A Snapshot of The Stages of Development of Upper-Level Physics Students". Journal of the Scholarship of Teaching and Learning. 2013. 13(4), 68-84.

[3] Sarabando, C., Cravino, J. P., \& Soares, A. A. "Contribution of a Computer Simulation To Students' Learning of The Physics Concepts of Weight and Mass”. Procedia Technology. 2014. 13, 112-121.

[4] Firdaus, T., Setiawan, W., \& Hamidah, I. "The Kinematic Learning Model Using Video and Interfaces Analysis". IOP Conf. Series: Journal of Physics: Conf. Series, 2017. 895(012108), 1-6.

[5] Rothenstein, B.,\& Zaharie, I. "Relativistic Thermodynamics for the Introductory Physics Course". Journal of Theoretics. 2003, 5-2, 1-8.

[6] Yener, D. “A Study on Analogies Presented In High School Physics Textbooks”. Asia-Pacific Forum on Science Learning and Teaching, 2012. 13(1), 1-17.

[7] Shirazi, S. "Student Experience of School Science". International Journal of Science Education, 2017. 39(14), 1891-1912.

[8] Greca, I. M.,\&Moreira, M. A. "Mental, Physical, and Mathematical Models in the Teaching and Learning of Physics". Science Education. 2011. 86, 106-121.

[9] Jacobson, M. J., \& Wilensky, U. "Complex Systems in Education: Scientific and Educational Importance and Implications for the Learning Sciences". Journal of The Learning Sciences. 2006 15(1), 11-34.

[10] Yoon, S. A., Goh, S. E., \& Park, M. "Teaching and Learning About Complex Systems in K-12 Science Education: A Review of Empirical Studies 1995-2015”. Review of Educational Research. 2017. 20(5), 1-41.

[11] Meredith, A. P. R., \& Volkmann, M. J. "Science and Mathematics-A Natural Connection". Science and Children, 2007. 45(2), 60-61.

[12] Goold, J., Huber, M., Riera, A., del Rio, L., \& Skrzypczyk, P. "The Role of Quantum Information In Thermodynamics-A Topical Review". J. Phys. A: Math. Theor. 2016. 49(0000) 143001, 1-50.

[13] Cheng, S. C., She, H. C., \& Huang, L. Y. "The Impact of Problem-Solving Instruction on Middle School Students' Physical Science Learning: Interplays of Knowledge, Reasoning, and Problem Solving". EURASIA Journal of Mathematics, Science and Technology Education. 2018.14(3), 731-743.

[14] Akben, N. "Effects of the Problem-Posing Approach on Students' Problem Solving Skills and Metacognitive Awareness in Science Education". Research in Science Education, 2018. 1-23.

[15] Wartono., Suyudi, A., \& Batlolona, J. R. "Students' Problem Solving Skills of Physics on the Gas Kinetic Theory Material". Journal of Education and Learning (EduLearn), 2018. 12(2), 319-324.

[16] Gormally, C., Brickman, P., Lutz, M. "Developing a Test of Scientific Literacy Skills (TOSLS): Measuring Undergraduates' Evaluation of Scientific Information and Arguments". CBE-Life Sciences Education, 2012. 11, 364-377.

[17] OECD. (2015). "Reviews of National Policies For Education: Education In Indonesia, Rising to The Challenge". Paris: OECD Publishing.

[18] Bell, T., Urhahne, D., Schanze, S., \& Ploetzner, R. "Collaborative Inquiry Learning: Models, Tools, and Challenges”. International Journal of Science Education, 2010. 32(3), 349-377.

[19] Helmreich, J. E.,\& Krog, K. P. “Ordinary Least Squares and Quantile Regression: An Inquiry-Based Learning Approach to a Comparison of Regression Methods". PRIMUS, 2017. 00(00), 1-17.

[20] Ajredini, F., Izairi, N., \& Zajkov, O. "Real Experiments versus Phet Simulations for Better High-School Students' Understanding of Electrostatic Charging". European Journal of Physics Education, 2013. 5(1), 59-70.

[21] Liu, T., C., Lin, Y. C., \& Kinshuk. "The application of Simulation-Assisted Learning Statistics (SALS) For Correcting Misconceptions and Improving Understanding of Correlation". Journal of Computer Assisted Learning, 2010. 26(2), 143-158.

[22] Han, I. "Impulse-Momentum Based Analysis of Vehicle Collisionaccidents Using Monte Carlo Simulation Methods". International Journal of Automotive Technology. 2015. 16(2), 253-270.

[23] Gall \& Borg, 2003. Education Research An Introduction. USA.

[24] Phet Colorado. 2018. https://phet.colorado.edu/sims/collision-lab/collision-lab_en.html.

[25] Han, I. "Impulse-Momentum Based Analysis of Vehicle Collisionaccidents Using Monte Carlo Simulation Methods". International Journal of Automotive Technology. 2015.16(2), 253-270.

[26] George, I. A., Broadstock, A. J., \& Abad, J. V. (2000). "Learning Energy, Momentum, and Conservation Concepts with Computer Support in an Undergraduate Physics Laboratory". Fourth International Conference of the Learning Sciences (pp. 2-3). Mahwah, NJ: Erlbaum.

[27] Unlu, P., Ingeç, S. K., \& Tasar M. F. "Investigation of Teacher Candidates Knowledge Structures About Momentum and Impuls by Means of Concept Maps”. Education and Science, 2006. 31(139), 70-79. 
[28] Sarioglan, A. B., \& Kucukozer, H. "Comparison of High School Students' Ideas about Momentum and Impulse Conceptions Before and After Instruction”. Procedia - Social and Behavioral Sciences, 2013. 116, 3771-3775.

[29] Marusic \& Slisko. "Influence of Three Different Methods of Teaching Physics on the Gain in Students' Development of Reasoning". International Journal of Science Education, 2012. 34(2), 301-326.

[30] Howes, E. V., Lim, M., \& Campos, J. "Journeys Into Inquiry-Based Elementary Science: Literacy Practices, Questioning, and Empirical Study”. Science Education. 2009. 93, 189-217.

[31] Wartono, W., Hudha, M. N., Batlolona, J. R. "How Are The Physics Critical Thinking Skills of The Students Taught by Using Inquiry-Discovery Through Empirical and Theorethical Overview?". Eurasia Journal of Mathematics, Science and Technology Education, 2018. 14(2), 691-697.

[32] Smith, R., \& Walker. S. "Can inquiry-based learning strengthen the links between teaching and disciplinary research?". Studies in Higher Education, 2010. 35(6), 723-740.

[33] Hugerat \& Kortam. "Improving Higher Order Thinking Skills among freshmen by Teaching Science through Inquiry". Eurasia Journal of Mathematics, Science \& Technology Education, 2014. 10(5), 447-454.

[34] Bacon, K.,\& Matthews, P. "Inquiry-Based Learning With Young Learners: A Peirce-Based Model Employed To Critique A Unit Of Inquiry On Maps And Mapping”. Irish Educational Studies, 2014. 33(4), 351-365. 